LAYMP9804127

UCRL-JC-129198

PREPRINT

\title{
MIC Evaluation and Testing for the Yucca Mountain Repository
}

\author{
JM. Horn \\ A. Rivera \\ T. Lian \\ D.A. Jones
}

This paper was prepared for submittal to the

Corrosion NACExpo 98

Annual Conference and Exposition

San Diego, CA

March 22-27, 1998

October 1997

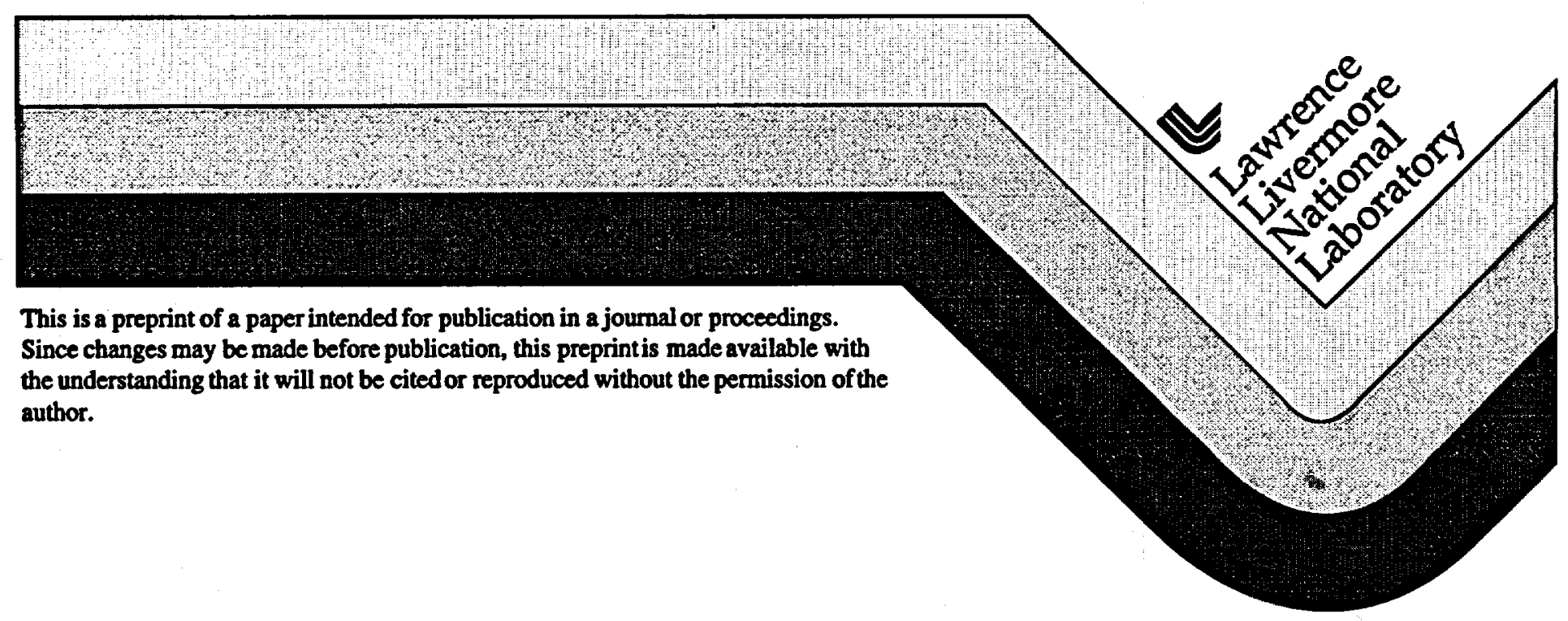




\section{DISCLAIMER}

This document was prepared as an account of work sponsored by an agency of the United States Government. Neither the United States Government nor the University of California nor any of their employees, makes any warranty, express or implied, or assumes any legal liability or responsibility for the accuracy, completeness, or usefulness of any information, apparatus, product, or process disclosed, or represents that its use would not infringe privately owned rights. Reference herein to any specific commercial product, process, or service by trade name, trademark, manufacturer, or otherwise, does not necessarily constitute or imply its endorsement, recommendation, or favoring by the United States Government or the University of California. The views and opinions of authors expressed herein do not necessarily state or reflect those of the United States Government or the University of California, and shall not be used for advertising or product endorsement purposes. 


\title{
MIC EVALUATION AND TESTING FOR THE YUCCA MOUNTAIN REPOSITORY
}

\author{
Joanne M. Horn \\ Angel Rivera \\ Lawrence Livermore National Laboratory \\ P.O. Box 808, L-206 \\ Livermore, CA 94550 \\ Tiangan Lian \\ Denny A. Jones \\ Chemical and Metallurgical Engineering \\ University of Nevada, Reno NV 89557
}

\begin{abstract}
Assessment of candidate waste package materials for nuclear waste disposal requires determination of any microbiological contribution to overall corrosion. Two systems employing characterized bacterial isolates from the Yucca Mountain site were designed to assess the rates of MIC on carbon steel $\mathrm{C1020}$ and Monel 400 in simulated groundwater. Microbial activities increased rates of carbon steel corrosion by a factor of. 5-6-fold compared to abiotic corrosion rates on the same material. Rates of biocorrosion of Monel 400 was 7-8-fold lower than that of $\mathrm{C1020}$. Cathodic reactions were equivalent between biotic and abiotic systems on $\mathrm{C1020}$, while the anodic reaction was activated on inoculated C1020 coupons. Further, while passivity was observed on sterile carbon steel, no such effect was demonstrated on inoculated samples. Novel corrosion cell designs were successful in obtaining rates of MIC on more corrosion-resistant candidate alloys.
\end{abstract}

Keywords: MIC, biocorrosion, polarization resistance, nuclear waste containment, Yucca Mountain 


\section{INTRODUCTION}

The U.S. Department of Energy is engaged in a suitability study for a potential deep geological repository at Yucca Mountain (YM), Nevada, for the containment and storage of high-level nuclear waste. There is growing awareness that biotic factors could affect the integrity of the repository directly through microbially induced corrosion (MIC) of waste package (WP) materials and other repository elements. A program to determine the degree that microorganisms, especially bacteria, influence the corrosion of waste package materials has therefore been undertaken. These studies include testing candidate waste package materials for their susceptibility to MIC, and also seek to determine rates of biocorrosion under varying environmental conditions, as well as predict rates of waste package corrosion over the long term.

Previous characterization of bacterial isolates derived from YM geologic material showed that many possessed biochemical activities associated with $\mathrm{MIC}^{1,2}$. Various Yucca Mountain microbes demonstrated the abilities to oxidize iron, reduce sulfate to sulfide, produce acids, and generate exopolysaccharides (or "slime"). Table 1 summarizes previously characterized YM organisms and their associated relevant activities.

A subset of the characterized YM bacteria were spread on WP alloy coupons in systems designed to collect polarization resistance $\left(R_{p}\right)$ data for corrosion rate calculations, and to determine cathodic and anodic potentiodynamic polarization to assess corrosion mechanisms. Coupons inoculated with bacteria were compared to those that remained sterile, to determine the bacterial contribution to overall corrosion rates.

\section{EXPERDMENTAL PROCEDURE}

Two types of corrosion cells were used to gather polarization resistance data. The Type I cell $^{3}$ consisted of a glass flat-bottom vessel filled with $100 \mathrm{ml}$ R2 bacterial growth media supplemented with $0.5 \%$ glucose and $0.75 \%$ proteose peptone \#3 (Difco) in $100 \mathrm{X} \mathrm{J} 13$ water (simulated groundwater from the YM site ${ }^{5}$ ) semi-solidified with $0.5 \%$ agar. The addition of agar produced a semi-solid electrolyte which retained inoculated bacteria near the specimen surfaces. The cell contained a working electrode ( 5 in. $L X 0.5$ in. $W X 0.032$ in. $D$, $21.4 \mathrm{~cm}^{2}$ surface area) and a platinum wire counter-electrode, as well as a Luggin capillary solution bridge filled with $1 \% \mathrm{KCl}$ in $1.5 \%$ agar. The Luggin bridge was connected to another glass vessel containing $1 \% \mathrm{KCl}$ and a saturated calomel reference electrode (SCE). A schematic diagram of a Type 1 corrosion cell is shown in Figure 1. All elements which camo into contact with the growth media were previously sterilized.

The Type 2 cell (Figure 2) was devised to improve the signal to noise ratio, and provide more consistent results for corrosion-resistant alloys. Type 2 cells consisted of a cylindrical glass flange with an O-ring seal to which the working electrode specimen was clamped, forming the bottom of the vessel. The disc-shaped metal coupons had a total exposed area of $28.3 \mathrm{~cm}^{2}$. Media volume (the composition remained as noted above) was increased to $450 \mathrm{ml}$ but remained fluid without agar addition, to better facilitate nutrient diffusion to the coupon surface. The SCE reference was directly immersed in the cell, along with the platinum counter electrode.

Working electrodes of $\mathrm{ClO20}$ carbon steel (which is similar in composition to the candidate material A516) and Monel 400 (M400) were wet-polished with abrasive paper 
progressively to 600-grit, cleaned with acetone and distilled water, and then autoclaved before being inoculated with mixture of 12 strains of YM bacteria (Table 1). The YM bacteria used for inoculation included acid and slime producers, as well as sulfate-reducing bacteria (SRB) and iron oxidizers. Cell densities were established before aseptically combining and spreading defined number (at least $10^{8}$ bacterial cells of each strain) of all isolates on coupons, coupons were then air dried before they were exposed to growth media in corrosion cells. Sterile control cells contained uninoculated working electrodes to assess abiotic corrosion effects.

The DC linear polarization technique was used to conduct polartization resistance (Rp) measurements in both Type 1 and Type 2 cells. A potentiostat (EG\&G Model 283) performed potential scans from $20 \mathrm{mV}$ less than the corrosion potential ( $E_{\text {corr }}$ ) to $20 \mathrm{mV}$ greater than

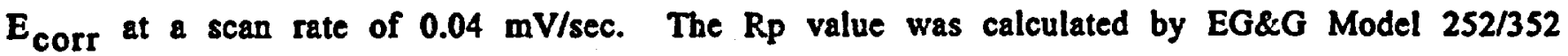
Softcorr II software.

To calculate corrosion rates, the measured $R_{p}$ values were converted to corrosion current $^{6}$ (icorr) expressed as $\mathrm{mA} / \mathrm{cm}^{2}$ :

$\mathbf{i}_{\mathrm{com}=\mathrm{B} / \mathrm{R}_{\mathrm{p}}}$

where $\quad B=B_{a} B_{0} / 2.303\left(B_{a}+B_{c}\right)$

Polarization measurements gave $B_{a}=B_{c}=0.15$ V/decade for the sterile carbon steel C1020, and $B_{a}=0.035 V / d e c a d e$ and $B_{C}=0.315 V / d e c a d e$ for $C 1020$ inoculated cells. The $i_{c o r r} w a s$ converted to corrosion rate $(r)$ in millimeters per year $(\mathrm{mm} / \mathrm{y})$ :

$$
r=3.27710^{-3} i_{c o m} a /(n D)
$$

where atomic weight $\mathrm{a}=56 \mathrm{~g}$, equivalent number $\mathrm{n}=2$, and

density $D=7.84 \mathrm{~g}_{\mathrm{cm}} \mathrm{cm}^{3}$ for carbon steel, and $a=60, \mathrm{n}=2, \mathrm{D}=8.84 \mathrm{~g} / \mathrm{cm}^{3}$ for $\mathrm{M400}$. Corrosion rates in $\mathrm{mm} / \mathrm{y}$ were converted to 0.001 in. per year (mpy) using the conversion 0.0254 $\mathrm{mm} / \mathrm{y}=1 \mathrm{mpy}$. For $\mathrm{M} 400$, the corrosion rate calculations. were based on $B_{\mathrm{a}}=B_{\mathrm{c}}=0.1 \mathrm{~V} / \mathrm{decade}$ since a Tafel range polarization determinations had not been determined.

\section{RESULTS}

Carbon Steel:Type 1 Cell

Replicate carbon steel C1020 coupons, in separate cells, showed evidence of corrosion in less than 24 . hours following inoculation with $Y M$ bacteria. MIC was evidenced by accumulation of corrosion products at the media-headspace interface, dark coloration of the coupon within the solidified media, and consistently low corrosion potentials. Sterile cells, on the other hand, did not show accumulation of corrosion products and maintained significantly higher corrosion potentials. Figure 3 depicts the changes in corrosion potentials on inoculated and sterile C1020 coupons over 62 day period. MIC in inoculated 
cells demonstrated an active Ecorr of approximately $-670 \mathrm{mV}$ versus SCE. After 5 days of incubation, inoculated cells had scattered microbial colonies distributed through the agar medium, and voids were observed to form within the media, which may be caused by gaseous end-products of microbial metabolism.

The corrosion rate of $\mathrm{Cl} 1020$ was significantly increased by exposure to inoculated bacteria (Figure 4). By day four following inoculation, the MIC rate was 1.67 mpy, 20 times greater than corrosion rates in parallel sterile cells ( $0.08 \mathrm{mpy})$. MIC rates in inoculated cells decreased, reaching a steady state rate of 1.35 mpy after two weeks. Concurrently, sterile cells showed an increase in corrosion rate during the same period, reaching 0.24 mpy after three weeks of incubation. Thus, the differential between corrosion rates on sterile and inoculated $\mathrm{C} 1020$ coupons was reduced to a factor of 5-6-fold, after a steady state had been achieved.

C1020 was not only observed to have a higher corrosion rate, but also developed corrosion-characteristic electrochemical properties in the biotic environment (Figure 5 ). The anodic polarization behavior of $\mathrm{ClO} 20$ in inoculated cells was highly active in anodic dissolution and demonstrated a low $B_{a}$ value (approximately 0.035 V/decade). Activation of the anodic reaction on inoculated coupons could be due to acid production or other localized effects caused by the bacteria. In contrast, sterile cells showed low corrosion rates at relatively high corrosion potentials (Figure 5). Thus, it appears that $\mathrm{C1020}$ has a relatively low corrosion rate in the anoxic environment that developed in nutrients and concentrated $\mathrm{J13}$ water when unexposed to microbes, but corrosion rates increase when $\mathrm{ClO20}$ is exposed to the mixture of bacteria selected for these experiments.

Figure 6 shows the comparison of cathodic polarization behavior in inoculated and sterile cells. The cathodic reaction displays similar properties between sterile and biotic cells, and it appears that both the biotic and abiotic systems display largely diffusion-controlled cathodic polarization in the inoculated cell. No apparent biotic affect on cathodic reduction processes, through hydrogen-depolarization by sulfate reducing bacteria, was discernible after eight days of incubation (Figure 6).

\section{Carbon Steel C1020 and Monel 400: Type 2 Cell}

Duplicate and triplicate Type 2 cells (Figure 2) containing disc-shaped coupons of C1020 . and M400, respectively, were inoculated with the same mixture of $12 \mathrm{YM}$ bacterial isolates (Table 1), and incubated in unsoldified media composed of $\mathbf{R 2}$ amended with glucose and peptone in $100 \mathrm{X} \mathrm{J} 13$ water; media was maintained in an aqueous state to facilitate diffusion of nutrients to inoculated bacteria. No sterile controls were included in these initial experiments.

The observed corrosion rate of $\mathrm{M400}$, as expected, was lower than those observed for C1020 (Figure 7). However, the corrosion rate of $\mathrm{M} 400$ increased nearly 3-fold during the first two weeks of incubation, while the C1020 decreased. Thus, even though there was an initial differential of 80 -fold in corrosion rate (0.012 mpy for M400 and 0.98 mpy for C1020), this was decreased to 7-8-fold after steady state was achieved (approximately 0.04 mpy for $\mathrm{M} 400$ and 0.3 mpy for $\mathrm{Cl020}$ ). 
The decrease in corrosion rate of the C1020 was much more marked than that observed in the cells using smaller coupons in the Type 1 cells (compare Figures 4 and 7). Since the coupon in these experiments was totally submerged in aqueous media, a uniform electrochemical condition rather than a local condition at the media-headspace interface, was created in these cells, and almost certainly contributed to the decrease in observed corrosion rates from one corrosion cell type to another.

Initially, at the start of the incubation period, redox potentials (as measured by a bare platinum electrode) of solution in M400 cells were more noble, at about $-180 \mathrm{mV}$ versus the reference electrode, compared to about $-400 \mathrm{mV}$ in C1020-containing cells. Since all other conditions were equivalent except the type of metal coupon, the increased $\mathrm{Fe}^{+2}$ in the $\mathrm{Cl020}$ cells, could have caused a greater consumption of oxygen by iron oxidizing bacteria, or C1020 may be more favorable to microbial growth generally, causing a greater degree of oxygen uptake by aerobic organisms. Alternatively, chemical oxidation of solubilized Fe+2 would deaerate the solution in $\mathrm{C1020}$ cells, and thereby lower redox potential. These results correlate well with observed corrosion potentials. The Ecorr of C1020 was on the order of $660 \mathrm{mV}$ versus the reference electrode, while that of the $\mathrm{M} 400$ increased from $-380 \mathrm{mV}$ to $300 \mathrm{mV}$ during continuous incubation.

Polarization resistance measurements using these larger coupons in the Type 2 cell design (Figure 2) improved signal quality significantly. Even while corrosion rates were low for M400 coupons, Rp measurements did not show noise or passive film effects.

\section{CONCLUSIONS}

The goals of these studies were to design and implement a system whereby the contribution of YM bacteria to overall corrosion rates of candidate WP alloys could be quantitatively determined. Further, we aimed to generate system whereby environmental factors could be altered, and candidate alloys could be tested for their relative susceptibilities to MIC. While our initial attempt (Figure 1) were sufficient to measure MIC on the more susceptible carbon steel coupons, background noise and resistance prevented sufficient signal resolution to determine MIC of more corrosion-resistant alloys. The signal to noise ratio was greatly improved by enlarging the size of the coupon and integrating the reference electrode directly into the same cell containing the working electrode (Figure 2). Development of this new cell type has permitted the evaluation of MIC of more corrosion resistant WP candidate alloys.

However, as noted above, since the coupon is entirely submerged, and the media remained unaerated throughout the incubation period, electrochemical conditions at the coupon surface were more uniform and more anoxic, as oxygen was presumably progressively consumed by aerobic microbial activities in the improved system. Thus, the enhancing of differential oxygen concentrations by microbial activities (causing waterline corrosion observed in the original cell design) was not observed in this latter system, and

corrosion rates were correspondingly depressed. Future modifications to this system may therefore include periodic or continual aeration of the media to better mimic prospective YM repository conditions, and obtain better estimates of MDC rates. 
Measured rates of corrosion on both inoculated and sterile coupons changed during the incubation period until they reached a "steady state" value. Initial elevated rates on inoculated coupons may reflect the ready availability of nutrients. Lower rates observed later in the incubation period could indicate exhaustion of the media immediately surrounding the alloy coupon or buildup of toxic endproducts. Since diffusion of nutrients and endproducts, especially in the agar-solidified system, would be minimal, it is expected that the observed "steady state" may not reflect that which would occur in a continuously fed system. Since water (and accompanying solutes) are expected to eventually invade the repository in a more-or-less continuous fashion, a continuously fed system may better reflect actual repository conditions, and provide a better measure of MIC over the long term.

Despite these caveats, it was possible using this system to discern a 5-6-fold increase in corrosion caused by inoculated bacterial to carbon steel coupons, and detect a 7-8-fold difference in MIC between carbon steel and Monel 400. Since corrosion rates were depressed in the latter type corrosion cell (Figure 2), microbial contributions to Monel 400 corrosion can not be discerned until sterile controls are included using this system.

\section{ACKNOWLEDGMENTS}

Work performed under the auspices of the U.S. Department of Energy by. Lawrence Livermore National Laboratory under Contract W-7405-ENG-48. This work was supported by the Yucca Mountain Site Characterization Project, LLNL.

\section{REFERENCES}

1. S.W. Borenstein, Microbiologically Influenced Corrosion Handbook (New York: Industrial Press Inc., 1994), pp.22-33.

2. J.M. Hom, B. Economides, A. Meike, RD. McCright, "Initial Studies to Assess Microbial Impacts on Nuclear Waste Disposal," International High Level Waste Management Conference, (Las Vegas, NV:1996).

3. D.A. Jones, B. Pitonzo, P.S. Amy, "Processes in Radioactive Waste Repository and Nuclear Fuel Storage Areas," J. Wolfram, R.D. Rogers, L.D. Gazso, eds., (Boston, MA:Kluwer, 1997), p. 23.

4. D.J. Reasoner, E.E. Geldreich, Appl. Environ' Microbiol 49 (1985): p.1.

5. J.M. Delany, "Reaction of Topopah Spring Tuff with J-13 water: a geochemical modeling approach using the EQ3/6 reaction path code,".

LINL UCRL Report-53631, 1985.

6. M. Stern, A.L. Geary, J. Electrochem. Soc. 104 (1957): p.56. 


\section{Table 1. Yucca Mountain Bacterial Isolates Displaying Corrosion-Related Activities}

\begin{tabular}{|c|c|c|c|c|c|c|c|}
\hline Strain\#" & Specles Identification ${ }^{b}$ & Acid & Production ${ }^{e}$ & Sulfide & Production ${ }^{d}$ & Slime & Production \\
\hline $\begin{array}{l}\text { "ESF-C1 } \\
\text { LB-71h-RT-13 } \\
\text { "ESF-71h-RT-4 } \\
\text { "LBan-U7 } \\
\text { LBan-UW2 } \\
\text { "LB-71h-50-3 } \\
\text { ESFan-U4 } \\
\text { LBan-C1 } \\
\text { LBan-UW2 } \\
\text { LBan-U1 } \\
\text { LBan-U2 } \\
\text { "LBan-U3 } \\
\text { LB-71h-50-2 } \\
\text { "LB-71h-50-4 } \\
\text { "LB-71h-50-6 } \\
\text { ESF-71h-RT-1 } \\
\text { "LB-C1 } \\
\text { LB-C2 } \\
\text { LB-C7 } \\
\text { "LB-71h-RT-15 } \\
\text { LB-71h-RT-4 } \\
\text { LB-CW-6 }\end{array}$ & $\begin{array}{l}\text { Cellulomonas flavlgena } \\
\text { Pseudomonas stutzeri } \\
\text { Flavobacterium esteroaromaticum } \\
\text { uncharacterized } \\
\text { Cellulomonas turbata } \\
\text { probably Bacillus sp. } \\
\text { Bacillus circulans } \\
\text { Arachnia propionica (poor match) } \\
\text { Cellulomonas turbata } \\
\text { Cellulomonas galtda } \\
\text { Bacillus pabull } \\
\text { Bacillus pantothenticus } \\
\text { Bacillus pumilus subgroup B } \\
\text { Bacillus subtllus } \\
\text { probably Bactllus sp. } \\
\text { Flavobacterium esteroaromaticum } \\
\text { uncharacterized } \\
\text { uncharacterized } \\
\text { Pseudomonas stutzeri } \\
\text { Pseudomonas pseudoflava } \\
\text { Pseudomonas pseudoflava } \\
\text { Arthrobacter oxydans }\end{array}$ & s. & $\begin{array}{l}\mathbf{x} \\
\mathbf{x} \\
\mathbf{x} \\
\mathbf{x} \\
\mathbf{x} \\
\mathbf{x} \\
\mathbf{x} \\
\mathbf{x} \\
\mathbf{x} \\
\mathbf{x} \\
\mathbf{x}\end{array}$ & . & $\begin{array}{l}X \text { (oxic/anoxic) } \\
X \text { (anoxic) } \\
X \text { (anoxic) } \\
X \text { (anoxic) } \\
X \text { (anoxic) } \\
X \text { (anoxic) } \\
X \text { (oxic) } \\
X \text { (oxic) } \\
X \text { (oxic) } \\
X \text { (oxic) }\end{array}$ & . & $\begin{array}{l}\mathbf{X} \\
\mathbf{x} \\
\mathbf{X} \\
\mathbf{x}\end{array}$ \\
\hline
\end{tabular}

* Used as inoculum for electrochemical determination of corosion rates with iron oxidizing and sulfate reducing enrichment cultures. "ESF=Exploratory Study Facility; LB=Large Block; an=isolated under anaerobic conditions; C=crushed rock isolate; Uruncrushed rock isolate; W=isolated from after washing rock; 71 h=isolated after. 71 hours of growth; RT=room temperature isolate; 50=50" $\mathrm{C}$. isolate 'Determined by fatty acid analysis using the MIDI/Hewlett Packard microbial identification system (MIS; Analytical Services, Inc., VT); identification of given isolates may be tentative due to a lesser degree of similarity with type organisms contained in the MIS database 'Determined after growth in $R 2$ media with or without $0.5 \%$ glucose and. pH indicators bromocresol purple and methyl red.

${ }^{d}$ Determined after growth in R2 agar media (Difco) containing $0.75 \%$ proteose peptone \#3 (Difco) and lead acetate

'Determined after growth on R2 agar (Difco). 


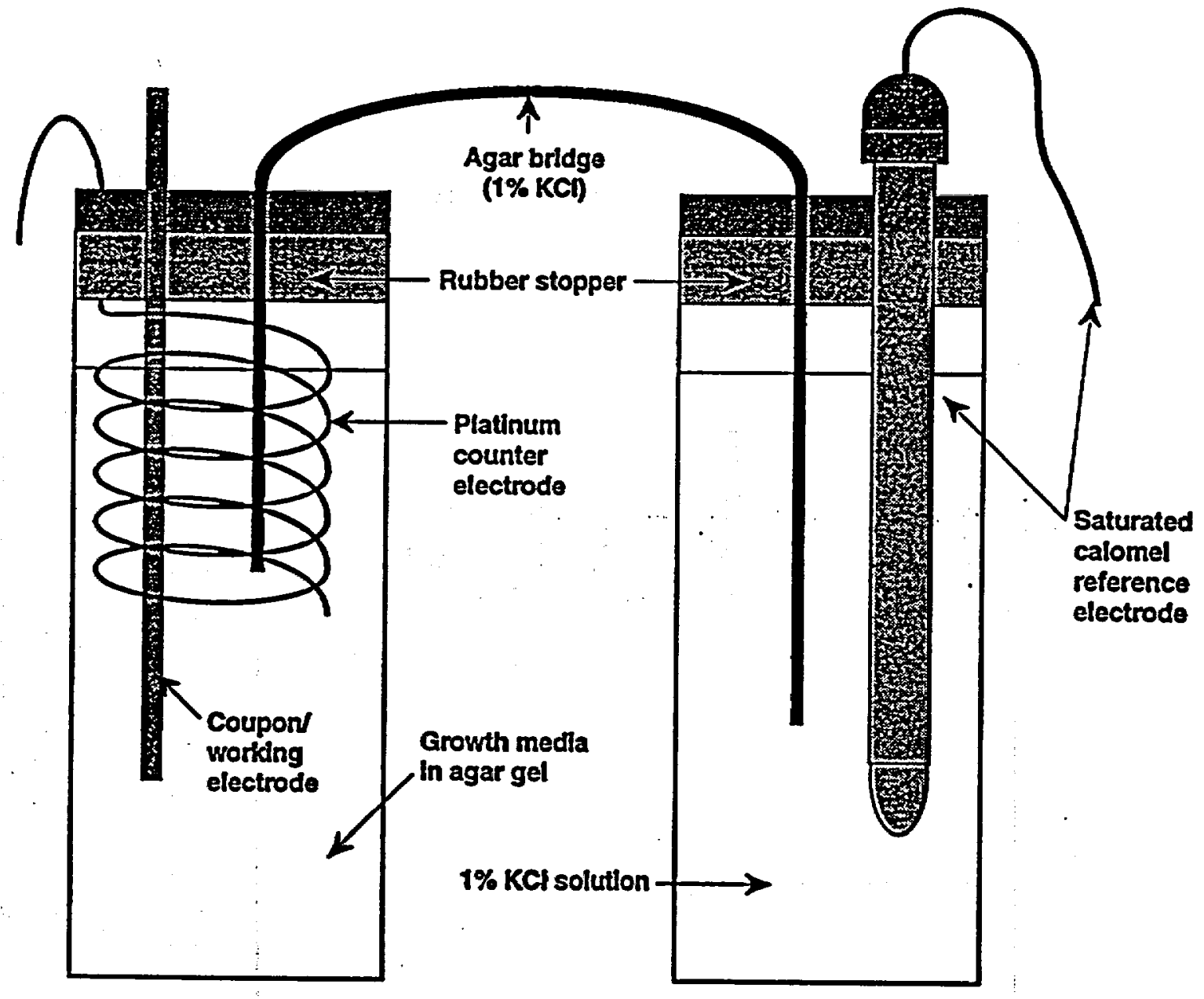

Figure 1. Configuration of corrosion cell for $21.4 \mathrm{~cm}^{2}$ carbon steel coupons. 


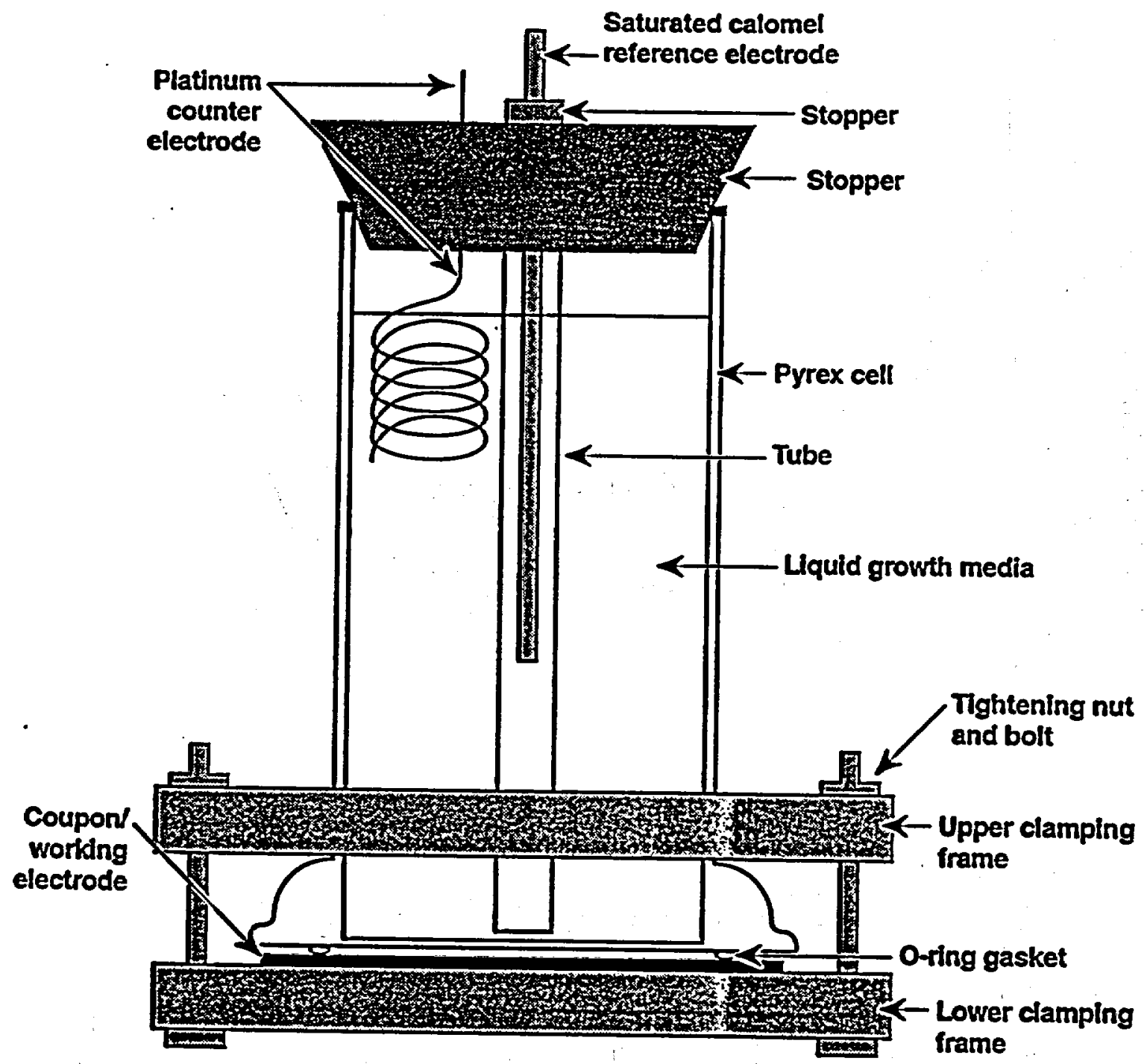

Figure 2. Configuration of corrosion cell for $28.3 \mathrm{~cm}^{2}$ carbon steel and Monel 400 coupons. 


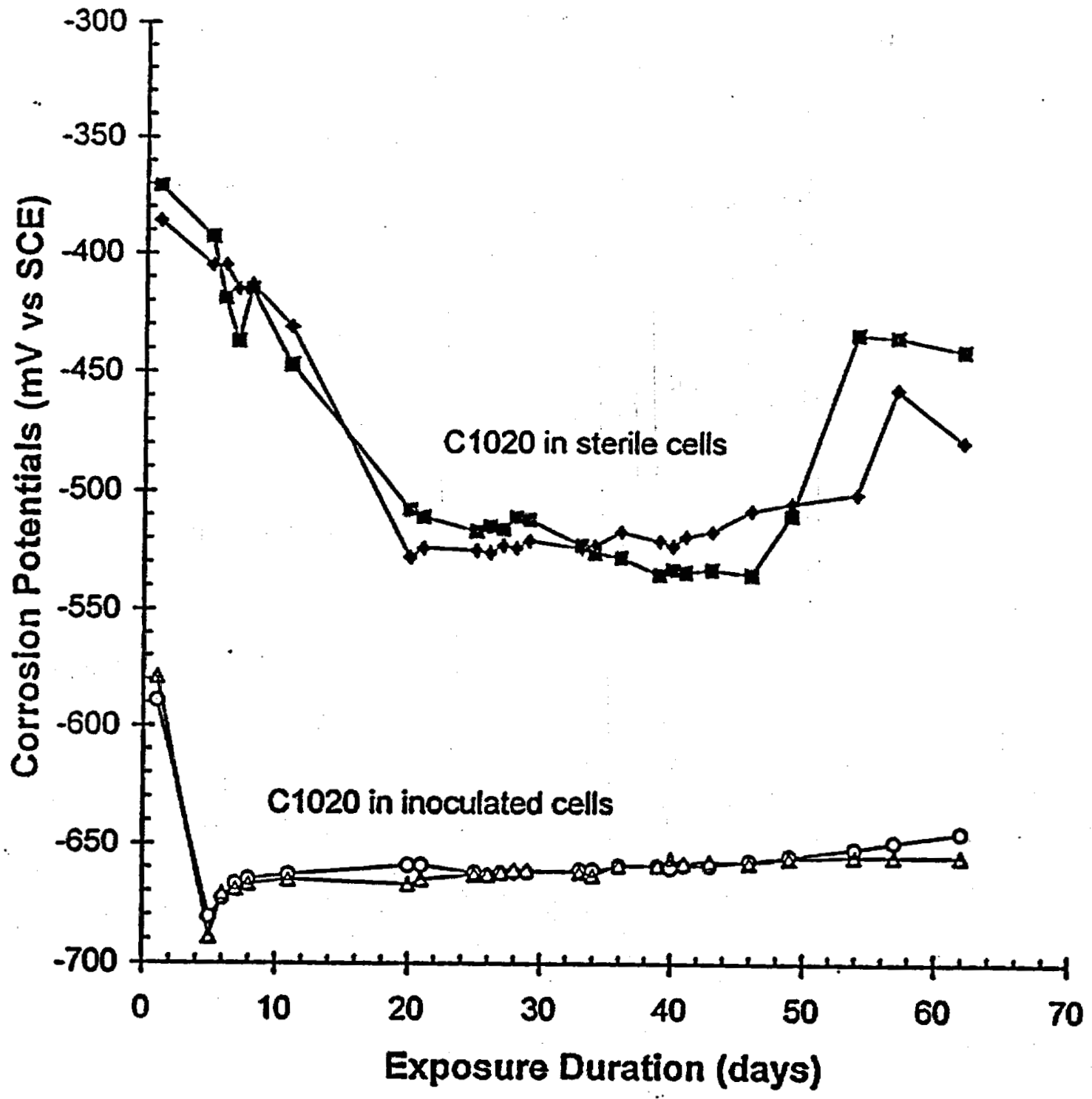

Figure 3. Change in corrosion potential as a function of incubation time on sterile (filied symbols) and inoculated (open symbols) $21.4 \mathrm{~cm}^{2}$ carbon steel C1020 coupons. Corrosion cell configuration was arranged as in Fig. 1. Each curve represents results trom a single corrosion cell. 


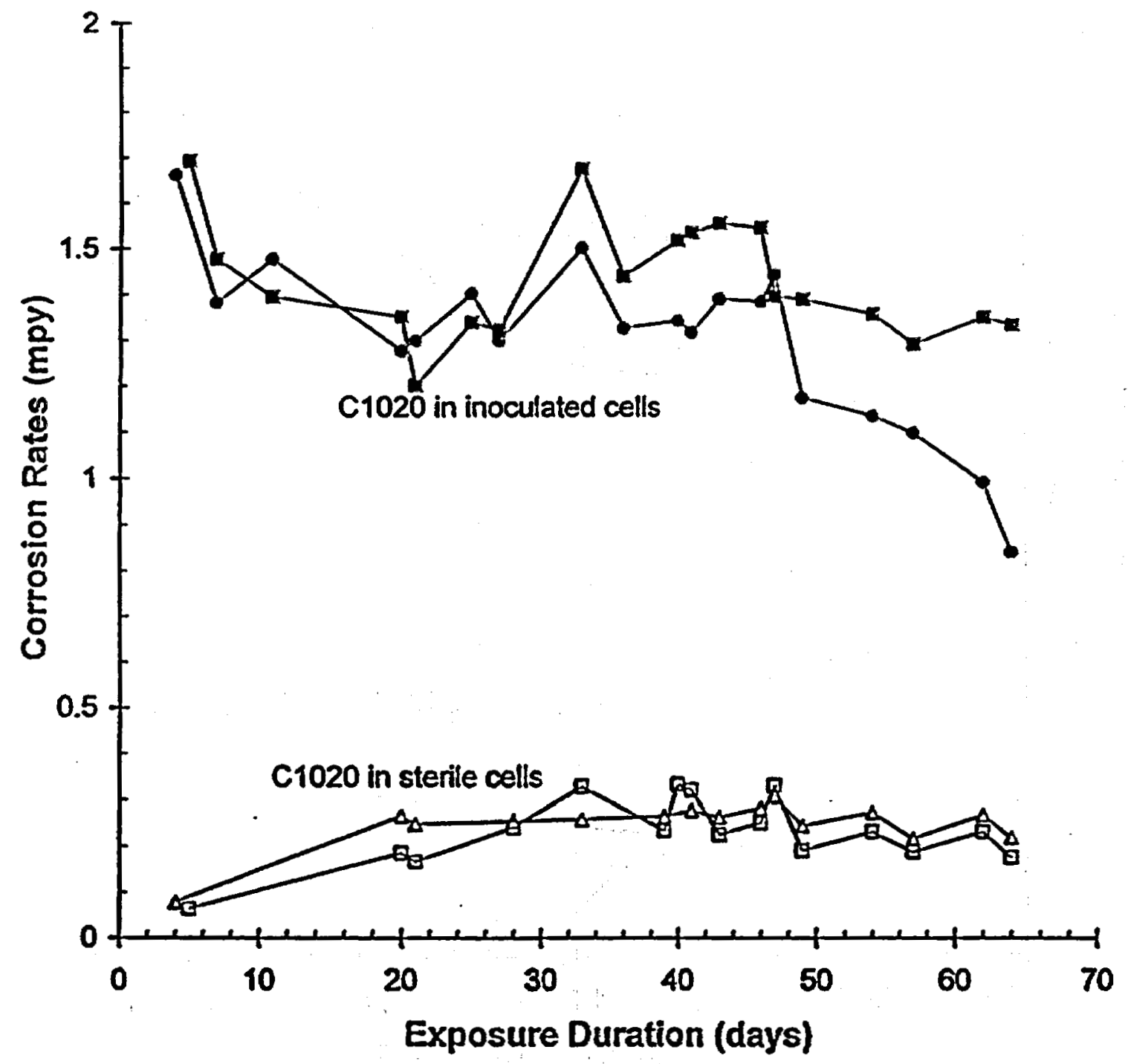

Figure 4. Corrosion rates of inoculated (closed symbols) and sterile (open symbols) carbon steel C1020 coupons. Corrosion cells were configured as shown in Fig. 1. Each curve represents results from a single trial. 


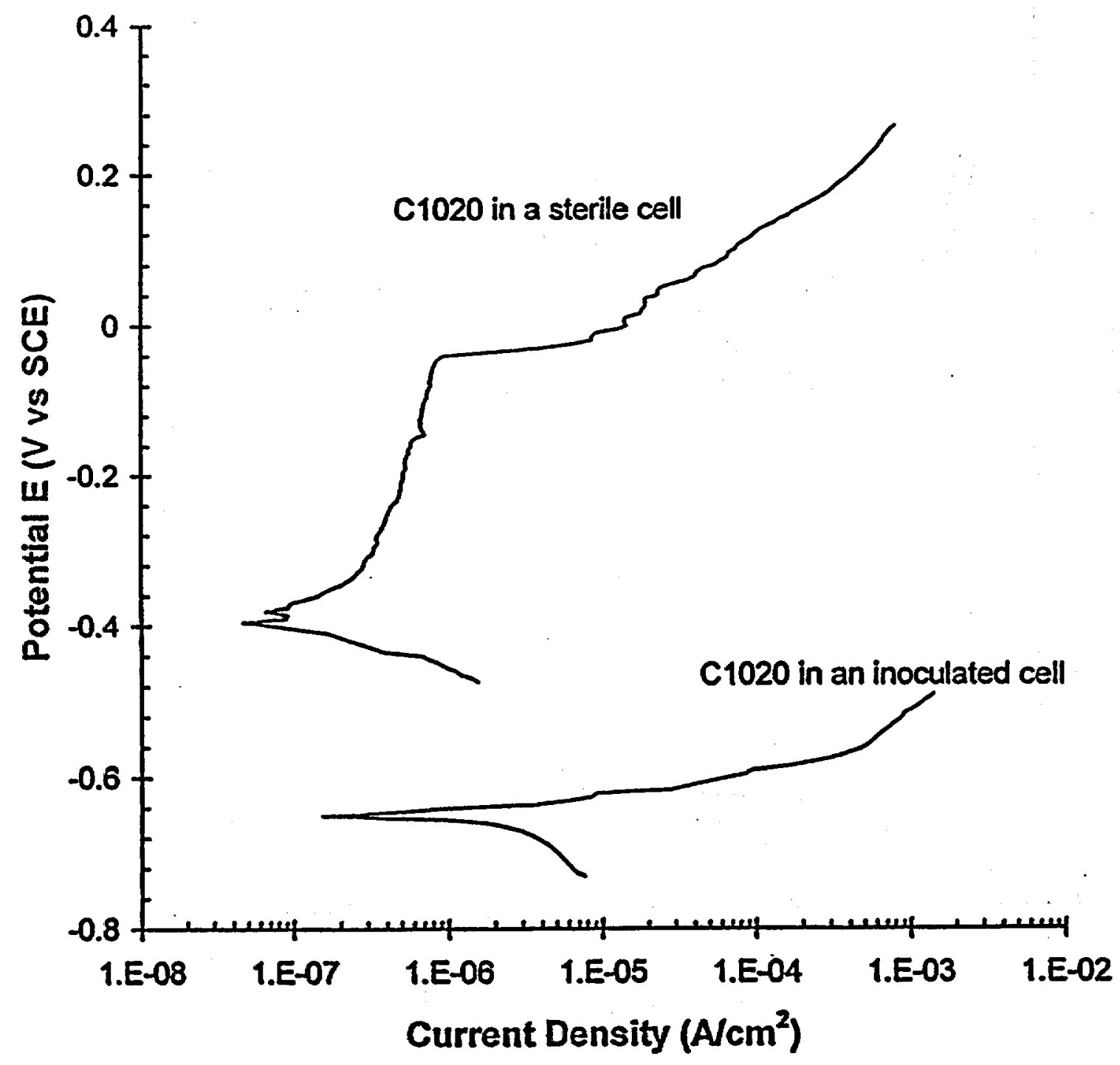

Figure 5. Anodic polarization of inoculated and sterile carbon steel C1020 coupons. Corrosion cells were configured as shown in Fig. 1. Representative data from single trials after eight days of incubation. 


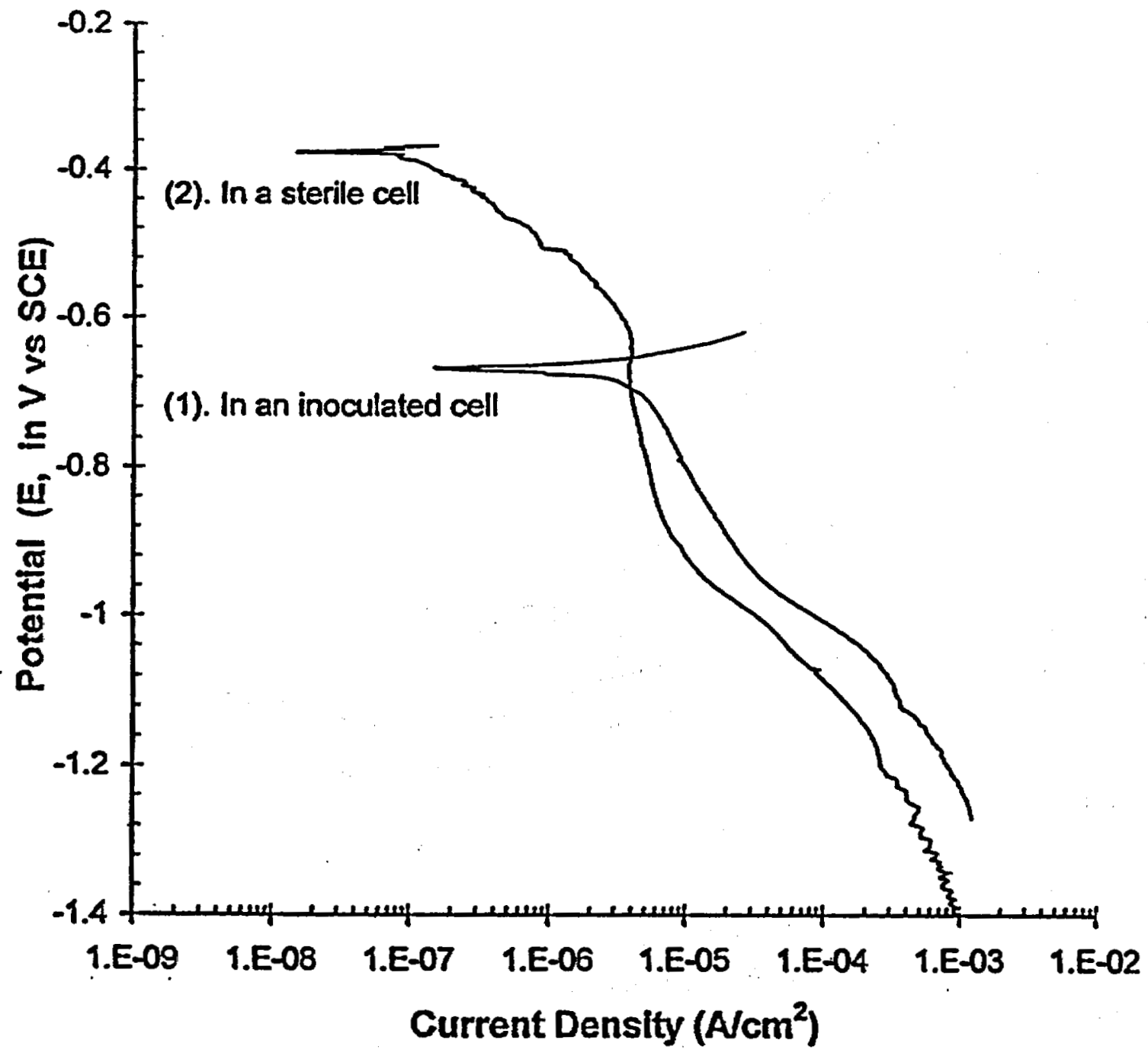

Figure 6. Cathodic polarization of inoculated and sterile coupons after eight days incubation. Corrosion cells configures as shown in Fig. 1. Representative data from single trials. 


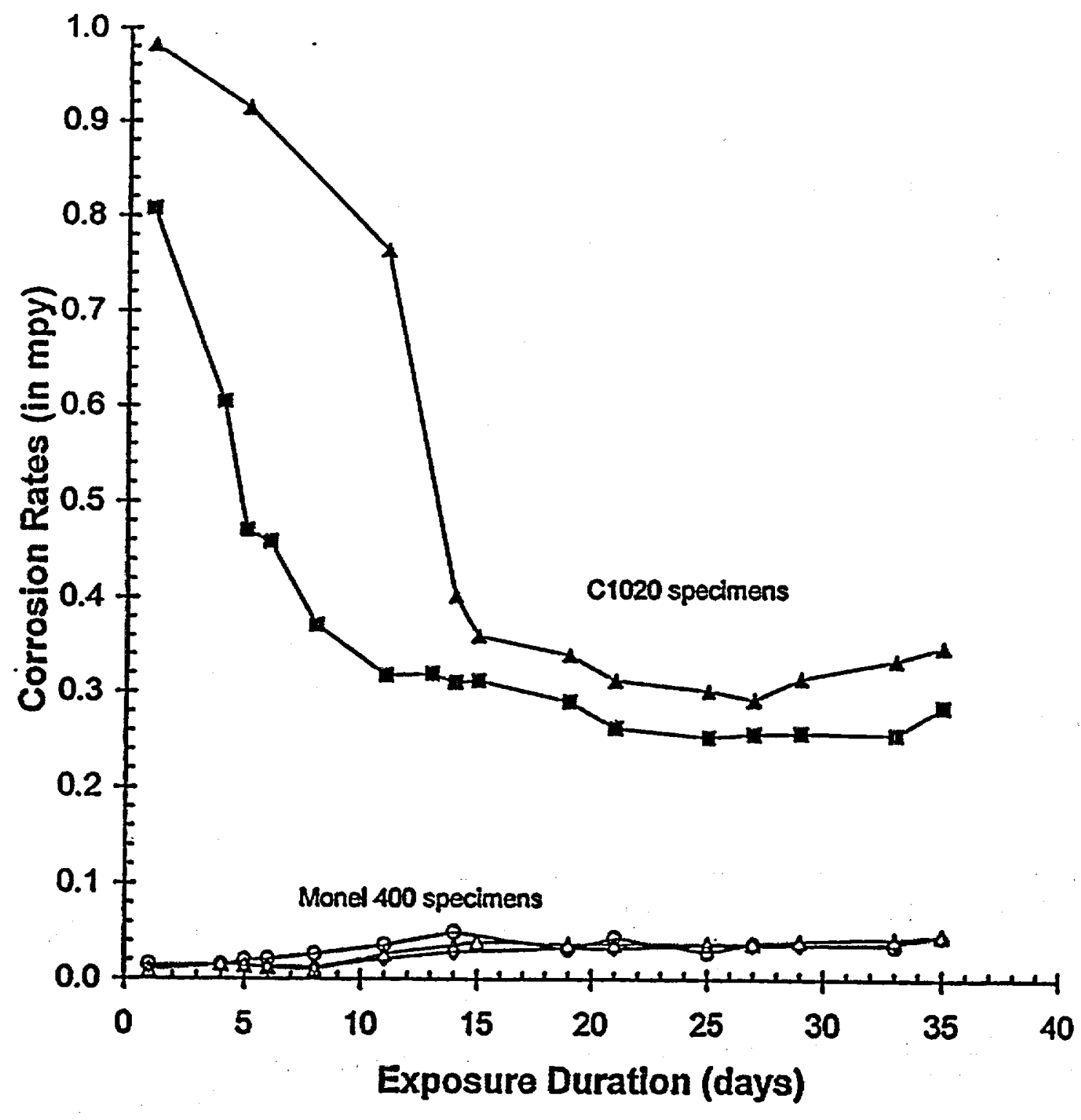

Figure 7. Corrosion of inoculated Monel 400 (open symbols) and carbon steel C1020 (closed symbols) as a function of incubation time. Corrosion cells were configured as shown in Fig. 2. Each curve represents data from a single trial. 
Technical Information Department $\bullet$ Lawrence Livermore National Laboratory University of California • Livermore, California 94551

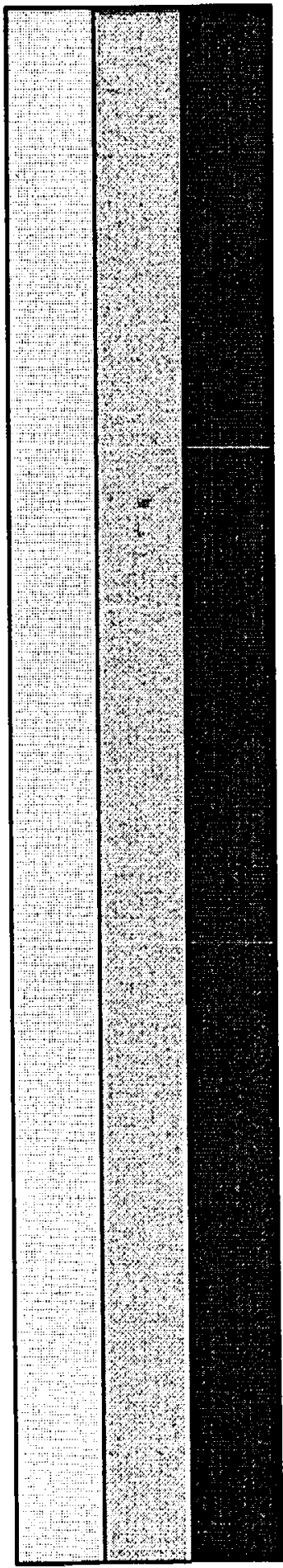

